\title{
Adopción de sistemas silvopastoriles y contexto sociocultural de los productores: apoyos y limitantes
}

\section{Adoption of silvopastoral systems and the sociocultural context of producers: support and limitations}

\author{
Rubén Manuel Zepeda Cancinoa, María Eugenia Velasco Zebadúaa, J osé Nahed Toralb, \\ Alfonso Hernández Garayc, Jaime J orge Martínez Tinajerod
}

\begin{abstract}
RESUMEN
El objetivo del estudio fue conocer la percepción de los productores de Mezcalapa, Chiapas, sobre la influencia de los factores: personal, sociocultural, apoyos gubernamentales y de instituciones académicas, en la adopción de los sistemas silvopastoriles (SSP). Se aplicó un cuestionario semi-estructurado a 23 productores, cuyas respuestas se verificaron en campo. El análisis mediante SPSS resultó en tres conglomerados con niveles alto, medio y bajo de desarrollo. Hubo diferencia $(P<0.05)$, respecto a la superficie cubierta de los SSP tecnificados (ha) y los metros lineales de cerco vivo por hectárea, entre los tres niveles del índice de desarrollo de los SSP (IDESSP) (P<0.05). En promedio, el $71 \%$ de los productores considera saber regular o poco sobre los SSP. El 86 \% de ellos opinó que las generaciones más jóvenes no tienen interés ni apego al campo. El apoyo de asesores con el modelo GGAVATT fue bueno para el $50 \%$ de ellos, pero indicaron que ha sido temporal. El 100, 74 y $62 \%$ de los productores con IDESSP alto, medio y bajo, respectivamente, han recibido apoyos de instituciones como ECOSUR y la UNACH. Los insumos agropecuarios, son poco accesibles para el $86 \%$ de ellos. Reciben \$ 4.20 por litro de leche y el $67 \%$ indicó que sus ingresos apenas cubren sus necesidades. Para el $93 \%$ de ellos el nivel de intermediarismo (coyotaje) les afecta. La edad, escolaridad, ingreso extra, escasos apoyos gubernamentales y falta de conocimiento de los productores, ha limitado la adopción en los SSP, en tanto que el apoyo complementario de instituciones académicas fue importante.
\end{abstract}

PALABRAS CLAVE: Adopción de tecnología, Sistemas silvopastoriles, Producción de leche, Trópico.

\begin{abstract}
The objective was to identify perceptions of farmers from Mezcalapa, Chiapas regarding the influence of personal and sociocultural factors, as well as support from the government and academic institutions in adoption of silvopastoral systems (SPS). A semi-structured questionnaire was applied to 23 farmers, whose answers were verified in the field. An SPSS analysis showed three conglomerates with high, medium and low levels of the SPS development index (SPSDI). Differences $(P<0.05)$ were found regarding area covered by SPS technician and for linear meters of living fence per hectare among the three levels of SPSDI. On average, $71 \%$ of farmers believe they know somewhat or little regarding SPS. Eighty six (86) percent believe that younger generations are not interested in farming. Support from Technology Transfer and Validation Farmer Group advisors was satisfactory for $\mathbf{5 0} \%$ of farmers but they indicated that such support has been temporary. One hundred percent, $74 \%$ and $62 \%$ of farmers with high, medium and low SPSDI, have received support from academic institutions. Eighty six \% of farmers have insufficient income to purchase agricultural inputs. Farmer's receive \$ 4.20 Mexican pesos per liter of milk and $67 \%$ indicate that their income barely covers their needs. I nterventions by intermediaries (middlemen) negatively affect $93 \%$ of these farmers. Age, educational level, extra income, low levels of government support, and farmer's lack of knowledge have limited adoption of SPS; therefore complementary support from academic institutions has played a critical role for these farmers.
\end{abstract}

KEY WORDS: Technology adoption, Silvopastoral systems, Milk production, Tropics.

Recibido el 14 de mayo de 2014. Aceptado el 28 de julio de 2014.

a Facultad de Medicina Veterinaria y Zootecnia. Universidad Autónoma de Chiapas. Rancho San Francisco Km. 8 Carretera Ejido Emiliano Zapata, Tuxtla Gutiérrez, Chiapas. México. mvelascoz@yahoo.com.mx. Correspondencia al segundo autor.

b Departamento de Agricultura, Sociedad y Ambiente. El Colegio de la Frontera Sur. San Cristóbal de las Casas, Chiapas. México.

c Programa de Ganadería, IREGEP. Colegio de Postgraduados. Montecillo, Texcoco, Estado de México. México.

d Facultad de Ciencias Agrícolas. Universidad Autónoma de Chiapas. Huehuetán, Chiapas. México. 


\section{INTRODUCCIÓN}

En el trópico mexicano, el sistema de producción bovino a base de pastoreo extensivo es el más utilizado debido a que es la forma más económica de alimentarlo; sin embargo, la degradación de las pasturas es la principal amenaza para la sostenibilidad del sistema. Esto se debe principalmente a factores de manejo entre los que se mencionan: las quemas para estimular el crecimiento de los pastos, el uso de agroquímicos, el manejo inadecuado del pastoreo (intensidad e intervalo de pastoreo y capacidad de carga animal de los potreros), que en consecuencia, reducen la productividad y rentabilidad de estos sistemas, debido al incremento en la adquisición de insumos externos para la manutención de los animales. Lo anterior ocasiona la expansión de la frontera ganadera, que implica la desforestación de bosques y disminución de los servicios ambientales de estos ecosistemas que contribuyen al calentamiento global que actualmente padece el planeta(1).

Una alternativa para una ganadería sustentable, son los sistemas silvopastoriles (SSP), que se basan en la interacción de plantas leñosas perennes (árboles o arbustos), leguminosas herbáceas y pastos, en diferentes arreglos y estratos para la alimentación del ganado bovino(2). En Latinoamérica, los SSP se han trabajado desde hace más de dos décadas, con resultados positivos para el productor y el medio ambiente, como: el aumento en la producción de carne y leche, disminución de la ocupación de insumos externos, una carga animal por hectárea más alta, reforestación, mitigación de gases de efecto invernadero, disminución de la erosión en el suelo, conservación de fuentes de agua y la restauración de flora y fauna $(1,3)$; sin embargo, el bajo capital para el establecimiento y la escasez de asistencia técnica y conocimientos, se consideran las principales barreras que limitan la adopción de estos sistemas $(4)$. Entre los proyectos con mayor impacto y éxito para la establecimiento de los SSP, se encuentra el de Enfoques Silvopastoriles

\section{INTRODUCTION}

In the Mexican tropics, animal production system based on extensive grazing is most widely used because it is the most economical way of feeding; however, pasture degradation is a major threat to the sustainability of the system. This is mainly due to management factors among which are: burning to stimulate pasture growth, the use of agrochemicals, inadequate grazing management (grazing intensity, grazing interval and animal carrying capacity of pastures) which consequently reduce productivity and profitability of these systems, due to increased acquisition of external inputs for animal management. This causes the expansion of the cattle frontier, which involves the deforestation of forests and reduction of environmental services from these ecosystems that contribute to global warming currently affecting the planet(1).

An alternative for sustainable farming, are silvopastoral systems (SPS), which are based on the interaction of woody perennials (trees or shrubs), herbaceous legumes and grasses in different arrangements and layers for feeding cattle(2) . In Latin America, SPS have operated for more than two decades, with positive results for the producer and the environment. These include increased production of meat and milk, reduced use of external inputs, animal loads higher per hectare reforestation, mitigation of greenhouse gases, reduced soil erosion, conservation of water sources and the restoration of flora and fauna $(1,3)$. However, shortage in capital funding for establishment and lack of technical assistance are considered the main barriers to the adoption of these systems(4). Among the projects with the greatest impact and success for the establishment of SPS, is the Silvopastoral Integrated Approaches for Ecosystem Management (2002-2007). It has been carried out in Costa Rica, Colombia and Nicaragua, and currently with the Colombian Sustainable Livestock Project (2010-2017). These projects are mainly based on providing technical assistance and incentive payments for 
Integrados para el Manejo de Ecosistemas (2002-2007) realizado en Costa Rica, Colombia y Nicaragua y actualmente el Proyecto de Ganadería Colombiana Sostenible (2010-2017); estos proyectos se basan principalmente en ofrecer asistencia técnica y un incentivo de pago por servicios ambientales (PSA) que en colaboración con instituciones de investigación y gubernamentales han potencializado la adopción de los SSP(5).

En México, la Red de Sistemas Silvopastoriles Intensivos (SSPi) liderada por el Centro para la Investigación en Sistemas Sostenibles de Producción Agropecuaria (CIPAV), de Colombia y la Fundación Produce A. C. del estado de Michoacán, en conjunto con instituciones académicas nacionales y la Secretaría de Agricultura Ganadería, Desarrollo Rural, Pesca y Alimentación (SAGARPA) lograron establecer cerca de 10 mil hectáreas de SSPi en 15 estados de la república en menos de cuatro años, mediante el ofrecimiento de semillas, asistencia técnica y un incentivo económico(6). En Chiapas, se ofrecen programas de apoyo a la ganadería por parte de la SAGARPA (Programa de estímulos a la productividad ganadera, PROGAN 2003) y la Secretaría del Campo (SECAM) a través del modelo Grupo Ganadero para la Validación y Transferencia de Tecnología (GGAVATT). Recientemente (2005), el Colegio de la Frontera Sur (ECOSUR) y la Universidad Autónoma de Chiapas (UNACH) en conjunto con las instituciones anteriores, han intervenido con talleres, cursos para productores y asesores GGAVATT, congresos y proyectos de investigación en el noreste del estado, destacando el potencial para el desarrollo de los SSP en esta área( 7,8$)$; sin embargo, a pesar de estos esfuerzos y los estudios realizados sobre aspectos tecnológicos, económicos y ambientales de los SSP, aparentemente existe poca adopción de estos sistemas, por lo que el objetivo del estudio fue conocer la influencia de los apoyos de instituciones gubernamentales y académicas, socioculturales y personales, sobre la decisión de los productores para optar o no por SSP, desde su propia perspectiva. environmental services (PES) in collaboration with research institutions and government have influenced the adoption of the SPS(5).

In Mexico, the Network of Intensive Silvopastoral Systems (iSPS) led by the Centre for Research on Sustainable Agricultural Production Systems (CIPAV) of Colombia and the Fundación Produce A.C. of the state of Michoacan, in conjunction with National academic institutions and the Secretariat of Agriculture, Livestock, Rural Development, Fisheries and Food (SAGARPA) were able to establish about 10 thousand hectares of iSPS in 15 states in the Republic in less than four years by offering seeds, technical assistance and financial incentives(6). In Chiapas, support programs for livestock are offered by SAGARPA (incentives program livestock productivity, PROGAN 2003) and the Secretariat of the Farm (SECAM) through the model Farm Group for Validation and Technology Transfer (GGAVATT). Recently (2005), the Colegio de la Frontera Sur (ECOSUR) and the Universidad Autónoma de Chiapas (UNACH) in conjunction with the above institutions have hosted workshops, courses for producers and advisors GGAVATT, conferences and research projects in the northeastern part of the state, highlighting the potential for development of iSPS in this area $(7,8)$. However, despite these efforts and studies on technological, economic and environmental impacts of SPS, apparently there is little adoption of these systems, thus the objective of this study was to determine the influence of support factors from governmental and academic institutions, sociocultural and personnel, on the decision of producers to choose whether or not to adopt SPS, from their own perspective.

\section{MATERIAL AND METHODS}

The study was conducted from September 2012 to November 2013, in the municipality of Mezcalapa, located in the region "III Mezcalapa" state of Chiapas at 170 08" N and 93o 18" W, $320 \mathrm{~m}$ asl. The climate is Af $(\mathrm{m})$ (warm humid with abundant rains in summer), annual average 


\section{MATERIAL Y MÉTODOS}

El estudio se realizó de septiembre 2012 a noviembre de 2013, en el municipio de Mezcalapa que se sitúa en la región "III Mezcalapa" del estado de Chiapas. A 170 08" N y 930 18" O, a $320 \mathrm{msnm}$. El clima es Af (m) (cálido húmedo con abundantes lluvias en verano), temperatura media anual de 24 a 26 ${ }^{\circ} \mathrm{C}$ y precipitación media anual de 1,932 mm.

Para efectuar el estudio, se formalizó un convenio con la Sociedad de Producción Rural Grupo Malpaso, integrada por 103 productores con unidades ganaderas (UGs) especializadas en la producción de leche. Los productores participantes contaban con SSP tradicionales (dejan crecer árboles dentro de sus praderas para leña y sombra, tienen cercos vivos para delimitar sus potreros o los límites de sus ranchos, pero no los utilizan para la alimentación animal), y con SSP tecnificados (donde además de las actividades tradicionales habían establecido árboles forrajeros dispersos en sus praderas, SSPi y bancos de proteína).

A partir de los resultados de un estudio alternativo en el que se condujeron tres talleres participativos con integrantes de esta SPR, se construyó un cuestionario semi-estructurado que incluyó una sección de datos sociodemográficos y se diseñó considerando los siguientes factores: apoyos gubernamentales, apoyos de instituciones académicas, sociocultural y personal, de acuerdo con la metodología de Morgan(9). Previa calibración y ajuste, se aplicó a 23 productores ( $22.3 \%$ de la población) en sus predios, para efectuar observaciones directas y cotejar la información.

El cuestionario contempló 39 indicadores a) cinco sociodemográficos: sexo, edad, escolaridad, religión y estado civil; b) seis para apoyos gubernamentales: experiencias con la SAGARPA y la SECAM, apoyos para mejorar el medio ambiente, opinión sobre el programa GGAVATT, gestión administrativa para la obtención de recursos y utilidad de estos; c) cinco para apoyos de instituciones académicas: asesoría, apoyo temperature 24 to $26^{\circ} \mathrm{C}$ and annual rainfall of $1,932 \mathrm{~mm}$.

To perform the study, an agreement was formally signed with the Society of Rural Production (SRP) Malpaso Group, consisting of 103 producers with livestock units (LUs) specialized in the production of milk. Participating producers had traditional silvopastoral systems (SPS, left to grow trees in their pastures for firewood and shade, have live fences to delimit their pastures or the limits of their ranches, but not for animal feed), and technified SPS (where in addition to traditional activities they have established scattered fodder trees in their pastures, iSPS and protein banks).

From the results of another study in which members of this SRP attended three participatory workshops, a semi-structured questionnaire was constructed that included a section of socio-demographic data that was designed to consider the following factors: governmental aid, academic institutional aid, sociocultural and personnel, according to the methodology of Morgan(9). Beforehand calibration and adjustment was done by applying it to 23 producers ( $22.3 \%$ of the population) in their properties to make direct observations and collate the information.

The questionnaire looked at 39 indicators a) Five sociodemographic: sex, age, education, religion and marital status; b) Six related to governmental support, experiences with SAGARPA and SECAM, support to improve the environment, GGAVATT opinion on the program, administrative management to obtain resources and usefulness of these; c) Five for support from academic institutions: consultancy, financial support, teaching courses, experimentation and presence in their ranches; d) nine for the sociocultural: group conceptions, annual earnings and additional income to livestock, level of intermediaries and behavior of younger generations towards farming; e) Seven for the personnel: degree of knowledge of SPS, frequency of introduction of trees, certified 
económico, impartición de cursos, experimentación y presencia en sus ranchos; d) nueve para el sociocultural: concepciones grupales, ganancias anuales e ingresos adicionales a la ganadería, nivel de intermediarismo y conducta de generaciones jóvenes hacia al campo; e) siete para el personal: grado de conocimiento de los SSP, frecuencia de introducción de árboles, certificado como productor orgánico, y opinión sobre los insumos agropecuarios.

Los datos se capturaron en Excel para el análisis por conglomerados de k-medias, mediante el paquete estadístico SPSS Ver. 20, con el que las unidades ganaderas se agruparon, conforme a un índice de desarrollo de los sistemas silvopastoriles (IDESSP), que se derivó de los indicadores siguientes: superficie de pastizales con árboles dispersos y cercos vivos, número total de vacas existentes, superficie de SSP tecnificados, metros lineales de cercos vivos y superficie total del rancho. Las diferencias entre los niveles del IDESSP, de los indicadores, se determinaron mediante análisis de varianza de una sola vía y la prueba de comparación de medias de Tukey $(P<0.05)$, y el análisis de $X^{2}$ para los no paramétricos (SPSS ver. 20).

\section{RESULTADOS Y DISCUSIÓN}

Resultaron tres conglomerados que consistieron en tres niveles del IDESSP: alto, medio y bajo, que agruparon a 4, 9 y 10 productores respectivamente, con UGs cuya superficie fue organic producer, and with an opinion regarding agricultural inputs.

The data were captured in Excel for cluster kmeans analysis, using SPSS Ver. 20, with the livestock units being grouped according to SPS development index (SPSDI). This index was derived from the following indicators: area of grassland with scattered trees and live fences, total number of existing livestock, surface area of technified SPS, linear meters of live fences and total area of the ranch. The differences between the levels of the SPSDI were determined by one way analysis of variance and the comparison test of Tukey $(\mathrm{P}<0.05)$, and analysis of $\mathrm{X}^{2}$ for nonparametric (SPSS Ver. 20).

\section{RESULTS AND DISCUSSION}

There were three clusters that consisted of three SPSDI levels: high, medium and low, that grouped to 4, 9 and 10 producers, respectively, with LUs with surface area from 10 to 109 ha. There was no difference between the levels of SPSDI indicator for grassland or with scattered trees in terms of cow/ha $(P>0.05)$. However, the differences between them was significant $(P<0.05)$ with surface area of technified SPS and live fences in linear meters per hectare (Table 1).

Socio-demographic data

Most producers of LUs irrespective of whether the SPSDI was high, medium and low were

Cuadro 1. Indicadores para el SPSDI de unidades ganaderas de Mezcalapa, Chiapas

Table 1. Indicators for Silvopastoral system development index (SPSDI) of livestock units in Mezcalapa, Chiapas

\begin{tabular}{lccc}
\hline & \multicolumn{3}{c}{ SPSDI } \\
\cline { 2 - 4 } Indicators & High $(n=4)$ & Medium $(n=9)$ & Low $(n=10)$ \\
\hline Grassland with scattered trees per cow per ha & $1( \pm 0.00)^{\mathrm{a}}$ & $0.89( \pm 0.11)^{\mathrm{a}}$ & $0.80(0.13)^{\mathrm{a}}$ \\
Silvopastoral systems technified, ha & $9( \pm 2.7)^{\mathrm{a}}$ & $1.56( \pm 0.60)^{\mathrm{b}}$ & $0.40( \pm 0.30)^{\mathrm{b}}$ \\
Linear meters of live fence per ha & $295.5( \pm 47.8)^{\mathrm{a}}$ & $198.5( \pm 36.3)^{\mathrm{ab}}$ & $122.8( \pm 16.2)^{\mathrm{b}}$ \\
\hline
\end{tabular}

In parenthesis is the standard error. $\mathrm{n}=$ population.

abc Values with different letters in the same row are different $(P<0.05)$. 
de 10 a 109 ha. No hubo diferencia entre los niveles del IDESSP para el indicador pastizales con árboles dispersos por vaca/ha ( $\mathrm{P}>0.05)$. Sin embargo, las diferencias entre estos fueron significativas $(P<0.05)$ para la superficie con SSP tecnificados y metros lineales de cerco vivo por hectárea (Cuadro 1).

\section{Datos sociodemográficos}

La mayoría de los productores con UGs de alto, medio y bajo IDESSP eran del sexo masculino, estaban casados y tenían una edad promedio de 58.5, 60.7 y 58.2 años, respectivamente (Cuadro 2), esto indica que algunos de ellos, ya son o están próximos a ser adultos mayores, que en parte, explica la poca adopción de SSP, como reportó Salas et al(10) en el norte de México, donde productores de edad avanzada fueron los que menos adoptaron nuevas tecnologías. El $75 \%$ de los productores con UGs de alto IDESSP eran católicos, mientras que 55.6 y $60 \%$ de ellos con medio y bajo IDESSP respectivamente, eran adventistas (no laboran los sábados). Es importante mencionar que el $50,55.6$ y $60 \%$ de los productores con alto, medio y bajo IDESSP respectivamente, alcanzaron sólo estudios de primaria; al respecto, en un estudio realizado por Marín et al(11) señalaron que la baja escolaridad es un indicador de pobreza que obstaculiza la adopción de los SSP. En los resultados de los factores, siete indicadores no fueron incluidos en los cuadros porque fueron contundentes y se aludieron directamente integrándolos a la discusión.

Factor apoyos gubernamentales

Los resultados indicaron que el $75 \%$ de los productores con UGs de alto IDESSP señalaron que su experiencia con la SAGARPA fue regular, mientras que fue buena para el 55.6 y $50 \%$ de los productores con medio y bajo IDESSP; esto se atribuye principalmente al apoyo del PROGAN (Cuadro 3). De igual forma, el 50, 66.7 y $60 \%$ de los productores con alto, medio y bajo IDESSP respectivamente, indicaron haber tenido
Cuadro 2. Datos sociodemográficos de productores con diferente SPSDI, en Mezcalapa, Chiapas

Table 2. Socio-demographic data with different Silvopastoral system development index (SPSDI) producers in Mezcalapa, Chiapas

\begin{tabular}{|c|c|c|c|}
\hline \multirow[b]{2}{*}{ Indicators } & \multicolumn{3}{|c|}{ SPSDI } \\
\hline & $\begin{array}{l}\text { High } \\
(n=4)\end{array}$ & $\begin{array}{l}\text { Medium } \\
(n=9)\end{array}$ & $\begin{array}{c}\text { Low } \\
(n=10)\end{array}$ \\
\hline \multicolumn{4}{|l|}{ Sex, \% } \\
\hline Male & 75 & 67 & 90 \\
\hline Female & 25 & 33 & 10 \\
\hline Age of producer & $58.5( \pm 5.7)$ & $60.7( \pm 3.5)$ & $58.2( \pm 4.1)$ \\
\hline \multicolumn{4}{|l|}{ Education, \% } \\
\hline Primary & 50 & 66.7 & 60 \\
\hline Secondary & 0 & 11.1 & 20 \\
\hline High School & 0 & 11.1 & 0 \\
\hline Bachelor of Arts & 50 & 11.1 & 20 \\
\hline \multicolumn{4}{|l|}{ Religion, \% } \\
\hline None & 25 & 22.2 & 0 \\
\hline Adventist & 0 & 55.6 & 60 \\
\hline Catholic & 75 & 22.2 & 40 \\
\hline \multicolumn{4}{|l|}{ Civil status, $\%$} \\
\hline Married & 75 & 77.8 & 90 \\
\hline Single & 0 & 11.1 & 10 \\
\hline Living together & 25 & 0 & 0 \\
\hline Widowed & 0 & 11.1 & 0 \\
\hline
\end{tabular}

$(P>0.05)$.

male, were married and had an average age of 58.5, 60.7 and $58.2 \mathrm{yr}$, respectively (Table 2). This indicates that some of them are already or they are about to become seniors, which partly explains the low adoption of SPS, as Salas et al(10) reported in northern Mexico, where producers of advanced years were less given to adopt new technologies. Farmers with LUs and high SPSDI were $75 \%$ Catholic, while 55.6 and $60 \%$ with medium and low SPSDI respectively, were Adventists (do not work on saturdays).

It is worth mentioning that 50, 55.6 and $60 \%$ of farmers with high, medium and low SPSDI, respectively, only had primary education. In this regard, a study by Marin et al(11) reported that low education is an indicator of poverty that hinders the adoption of the SPS. In the results 
buena experiencia con la SECAM, posiblemente debido a la asistencia técnica que otorgó desde hace cinco años al 50, 70 y $77.8 \%$ de los productores con alto, medio y bajo IDESSP respectivamente, a través del programa GGAVATT, orientado a la certificación en la producción de leche orgánica. Es posible que por lo anterior, el 50, 55.6 y $50 \%$ de los productores con alto, medio y bajo IDESSP respectivamente, opinaran que el funcionamiento del programa GGAVATT ha sido bueno aunque temporal y suficiente para certificar a la mayoría of the factors, seven indicators were not included in the tables because they were definitive and were alluded to and integrated directly into the discussion.

Government support factor

The results indicated that $75 \%$ of producers with LUs that had high SPSDI said their experience with the SAGARPA was average, while it was good for 55.6 and $50 \%$ of farmers with medium and low SPSDI, this is mainly

Cuadro 3. Factor de apoyos gubernamentales en productores con diferente SPSDI, en Mezcalapa, Chiapas (\%)

Table 3. Governmental support factors with producers different values of Silvopastoral system development index (SPSDI) in Mezcalapa, Chiapas (\%)

\begin{tabular}{|c|c|c|c|}
\hline \multirow[b]{2}{*}{ Indicators } & \multicolumn{3}{|c|}{ SPSDI } \\
\hline & High $(n=4)$ & Medium $(n=9)$ & Low $(n=10)$ \\
\hline \multicolumn{4}{|c|}{ Experience with SAGARPA: } \\
\hline Good & 25 & 55.6 & 50 \\
\hline Average & 75 & 44.4 & 40 \\
\hline Poor & 0 & 0 & 10 \\
\hline \multicolumn{4}{|c|}{ Experience with SECAM: } \\
\hline Good & 50 & 66.7 & 60 \\
\hline Average & 50 & 0 & 30 \\
\hline Poor & 0 & 22.2 & 0 \\
\hline None & 0 & 11.1 & 10 \\
\hline \multicolumn{4}{|c|}{ Received support from programs to improve the environment: } \\
\hline Very often & 0 & 0 & 0 \\
\hline Often & 25 & 0 & 0 \\
\hline Regularly & 0 & 11.1 & 0 \\
\hline Unfrequently & 25 & 44.4 & 20 \\
\hline Uncommon & 50 & 44.4 & 80 \\
\hline \multicolumn{4}{|c|}{ Support GGAVVAT: } \\
\hline Good & 50 & 55.6 & 50 \\
\hline Average & 25 & 22.2 & 30 \\
\hline Poor & 25 & 11.1 & 20 \\
\hline \multicolumn{4}{|c|}{ How would you rate the support of government programs: } \\
\hline Very useful & 25 & 33.3 & 10 \\
\hline Useful & 25 & 33.3 & 50 \\
\hline Average & 50 & 33.3 & 30 \\
\hline Poor & 0 & 0 & 0 \\
\hline Very poor & 0 & 0 & 10 \\
\hline
\end{tabular}


de los productores que recibieron asesoría. Esto coincide con un estudio realizado en Colombia, donde la capacitación a productores influyó positivamente en la adopción de nuevas tecnologías(12), por lo que, enfocar las asesorías del GGAVATT al establecimiento de los SSP, incrementaría la adopción y desarrollo de estos sistemas en la región, sobre todo, porque el $50,44.4$ y $80 \%$ de los productores en los niveles alto, medio y bajo del IDESSP refirieron que no es frecuente recibir apoyos de programas para mejorar el medio ambiente, lo cual también los limita, debido a la escasez de políticas públicas que promuevan la conservación del medio ambiente, a través del establecimiento de SSP. Esto coincide con Casasola et al(13) quienes en Costa Rica, destacaron que es de vital importancia la eficiencia de políticas públicas con apoyo de incentivos económicos (pagos por servicios ambientales) y de asistencia técnica para potencializar la adopción de los SSP. Por otra parte, salvo en el nivel medio del IDESSP, la mayoría de los productores en los dos niveles restantes, calificó de regular utilidad a útiles, los apoyos económicos de programas gubernamentales; respecto a lo accesible, adecuado y efectivo de la gestión administrativa para la obtención de dichos recursos, el $50 \%$ de los productores con alto IDESSP señaló que son poco accesibles y que deberían autorizarse trámites individuales no sólo colectivos, en tanto que, fueron accesibles y regularmente accesibles para los productores con niveles medio (44.4\%) y bajo del IDESSP (40 \%). La gestión administrativa fue poco adecuada y efectiva para el $50 \%$ de los productores con alto IDESSP, mientras que fue muy adecuada y efectiva para los de nivel medio (44\%) y regularmente adecuada y efectiva para los de nivel bajo del IDESSP (50 \%), lo que resultó bastante polémico. Adicionalmente, señalaron que el $100 \%$ de los productores de los tres niveles del IDESSP no cuentan con seguro médico por las actividades pecuarias que realizan.

Factor apoyos de instituciones académicas

A este respecto, el 100, 70 y $55.6 \%$ de los productores con alto, medio y bajo IDESSP attributed to the support PROGAN (Table 3). Similarly, 50, 66.7 and $60 \%$ of farmers with high, medium and low SPSDI respectively, reported having had a good experience with the SECAM, possibly due to the technical assistance granted for five years at 50, 70 and $77.8 \%$ of producers with high, medium and Iow SPSDI, respectively, through GGAVATT program, aimed at certification in the production of organic milk. It is possible that the above, $50,55.6$ and $50 \%$ of farmers with high, medium and low SPSDI respectively, had the opinion that the operation of GGAVATT program had been good but temporary and sufficient to certify the majority of producers who received the counseling. This coincides with a study conducted in Colombia, where trained producers positively influenced the adoption of new technologies(12). Thus, focusing on the advice given by GGAVATT, the establishment of SPS increases with the adoption and development of these systems in the region, especially because $50,44.4$ and $80 \%$ of producers in the high, average and low levels of SPSDI reported that they did not often receive aid from programs to improve the environment, which was also limited due to the lack of public policies that promote environmental conservation through the establishment of SPS. This coincides with Casasola et al(13) in Costa Rica where they stressed that it is vital to the efficiency of public policies to support economic incentives (payments for environmental services) and technical assistance to incentivize the adoption of the SPS. Moreover, except at the average level of SPSDI, most producers at the remaining two levels indicated that economic support from government programs is useful. Regarding accessibility, they affirmed it is adequate and effective the administrative management to obtain these resources, $50 \%$ of farmers with high SPSDI said that are not easily accessible and they should be allowed not only collective individual procedures, while were accessible and regularly accessible to producers with average $(44.4 \%)$ and low (40 \%) levels of the SPSDI. The administration was inadequate and effective 
respectivamente, han recibido apoyo por parte del ECOSUR; el $75 \%$ de los productores con alto IDESSP señalaron que los investigadores del ECOSUR utilizan sus ranchos para desarrollar trabajos de investigación, mientras que sólo con el 33.3 y $10 \%$ de los productores con medio y bajo IDESSP han desarrollado dicha actividad (Cuadro 4). El 100 y $75 \%$ de los productores con alto IDESSP han recibido apoyo de asesorías y de tipo económico respectivamente, mientras que, el 33.3 y $50 \%$ de los productores con medio y bajo IDESSP sólo han recibido cursos (Figura 1). Adicionalmente, el $50 \%$ de los productores con alto IDESSP refirieron que fue for $50 \%$ of farmers with high SPSDI, while it was very appropriate and effective for mid-level (44\%) and regularly adequate and effective for low level SPSDI (50\%), which was quite controversial. In addition, they noted that $100 \%$ of the producers at the three levels of SPSDI without health insurance for livestock activities they perform.

Aid factors from academic institutions In this regard, 100, 70 and $55.6 \%$ of producers with high, medium and low SPSDI, respectively, or have received support from ECOSUR; $75 \%$

Cuadro 4. Intervención de instituciones académicas en productores con diferente SPSDI, en Mezcalapa, Chiapas

Table 4. Intervention of Silvopastoral system development index Silvopastoral System Development Index (SPSDI), in the municipality of Mezcalapa, Chiapas

\begin{tabular}{|c|c|c|c|}
\hline \multirow[b]{2}{*}{ Institution/Indicators } & \multicolumn{3}{|c|}{ SPSDI } \\
\hline & High $(n=4)$ & Medium $(n=9)$ & Low $(n=10)$ \\
\hline \multicolumn{4}{|l|}{ ECOSUR } \\
\hline \multicolumn{4}{|c|}{ Have you received support? } \\
\hline Yes & 100 & 70 & 55.6 \\
\hline No & 0 & 30 & 44.4 \\
\hline \multicolumn{4}{|c|}{ Was your ranch used in research? } \\
\hline Yes & 75 & 33.3 & 10 \\
\hline No & 25 & 66.6 & 90 \\
\hline \multicolumn{4}{|l|}{ Presence in LUs, } \\
\hline Good & 25 & 22.2 & 0 \\
\hline Average & 50 & 11.1 & 10 \\
\hline Poor & 25 & 0 & 20 \\
\hline None & 0 & 66.6 & 70 \\
\hline \multicolumn{4}{|l|}{ UNACH } \\
\hline \multicolumn{4}{|c|}{ Have you received support? } \\
\hline Yes & 100 & 77.8 & 70 \\
\hline No & 0 & 22.2 & 30 \\
\hline \multicolumn{4}{|c|}{ Was your ranch used in research? } \\
\hline Yes & 75 & 33.3 & 10 \\
\hline No & 25 & 66.6 & 90 \\
\hline \multicolumn{4}{|l|}{ Presence in LUs, } \\
\hline Good & 50 & 44.4 & 10 \\
\hline Average & 25 & 0 & 10 \\
\hline Poor & 25 & 0 & 10 \\
\hline None & 0 & 55.6 & 70 \\
\hline
\end{tabular}

$(P>0.05)$. LUs $=$ Livestock units. 
regular la presencia del ECOSUR en sus ranchos, en tanto que, no existió presencia de esta institución en los ranchos del 66.6 y 70 \% de los productores con medio y bajo IDESSP. Respecto a la intervención de la UNACH, el $100,77.8$ y $70 \%$ de los productores con alto, medio y bajo IDESSP respectivamente, han recibido apoyo por parte de esta institución; el $75 \%$ de los productores con alto IDESSP indicaron que la UNACH utiliza sus ranchos para investigación, mientras que, el 66.6 y $90 \%$ de los productores con medio y bajo IDESSP señalaron que no han utilizado sus ranchos (Cuadro 4). El $75 \%$ de los productores con alto IDESSP han recibido apoyo en asesorías, en cambio, el 55.6 y $50 \%$ de los productores con medio y bajo IDESSP, sólo han recibido cursos (Figura 1); de igual forma, el $50 \%$ de los productores con alto IDESSP señalaron que es mucha la presencia de la UNACH en sus ranchos y como ocurrió con la institución of farmers with high SPSDI noted that researchers of ECOSUR use their ranches to develop research, while only 33.3 and $10 \%$ of farmers with medium and low SPSDI have developed such activity (Table 4). High SPSDI producers have received support in the form of instructional assistance and economic, 100 and $75 \%$ respectively. While 33.3 and $50 \%$ of farmers with medium and low SPSDI have only received courses (Figure 1 ). In addition, $50 \%$ of producers with high SPSDI reported that the presence of ECOSUR on their ranches was average, whereas, there was no presence of this institution on the ranches of 66.6 and $70 \%$ of farmers with medium and low SPSDI. Regarding the intervention of the UNACH, 100, 77.8 and $70 \%$ of farmers with high, medium and low SPSDI respectively, said they have received support from this institution; $75 \%$ of producers with high SPSDI indicated that UNACH

Figura 1. Apoyos de instituciones académicas a las unidades con niveles alto, medio y bajo del SPSDI, en Mezacalapa, Chiapas

Figure 1. Academic institutional support to units with high, average and low levels of Silvopastoral system development index SPSDI, in Mezacalapa, Chiapas

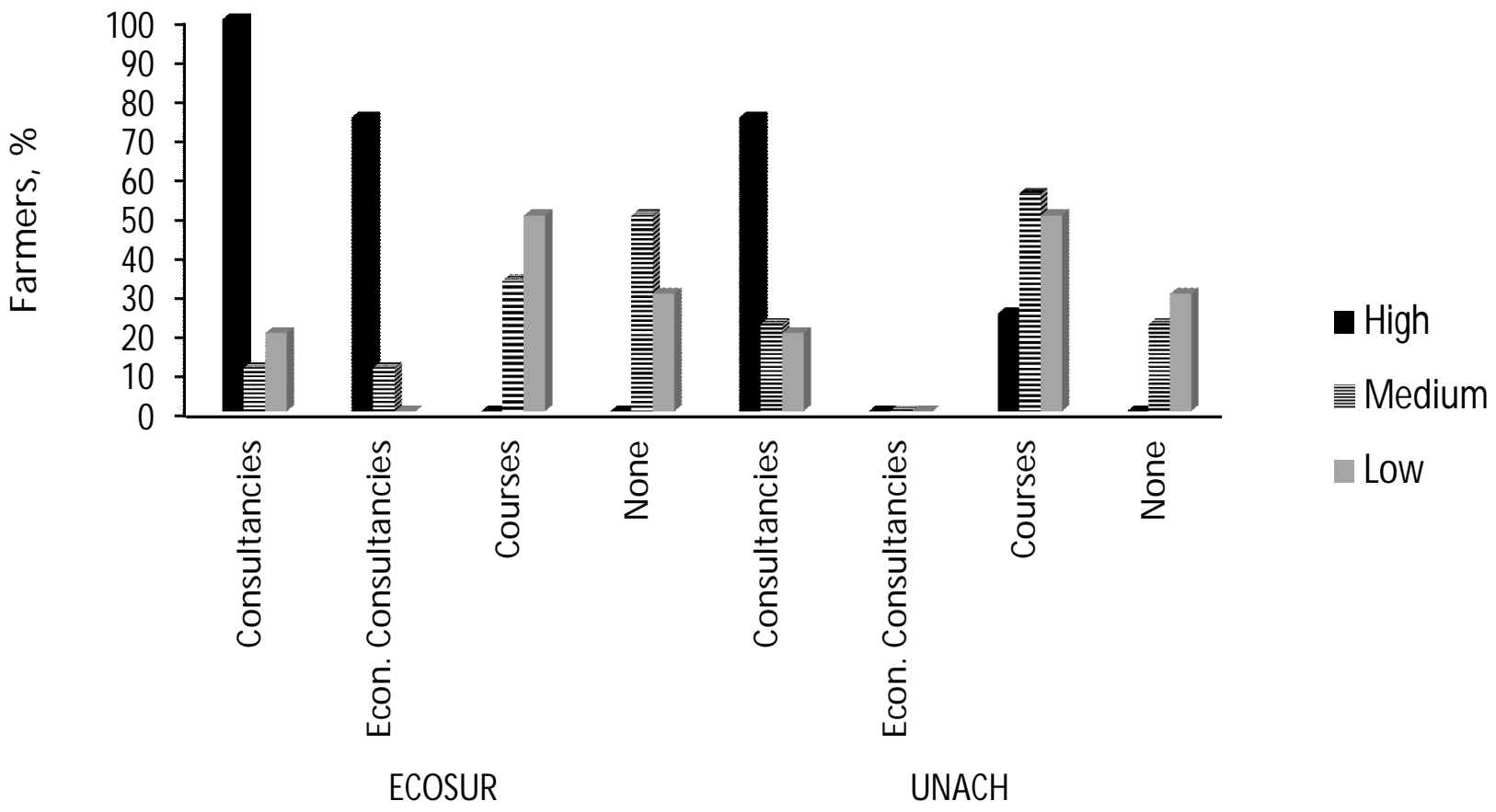


anterior, el 55.6 y $70 \%$ de los productores con medio y bajo IDESSP señalaron que no existió presencia de la UNACH en sus UGs. De acuerdo a los resultados anteriores, se puede notar que los productores con alto IDESSP han tenido mayor intervención por parte de las instituciones académicas y han recibido mayor apoyo en cuanto a asesorías, apoyos económicos y presencia en sus ranchos, lo que justifica que tengan un mejor desarrollo de SSP. Este resultado coincide con los estudios realizados en Costa Rica y Colombia donde consideran que el apoyo en asistencia técnica, más el de incentivos económicos facilita la adopción de los SSP $(14,15)$, así también, se menciona que la intervención de instituciones académicas es vital para la adopción de estos sistemas(16).

Factor sociocultural

El $100 \%$ de los productores con alto IDESSP tienen otro ingreso económico además de la ganadería, mientras que el 77.8 y $60 \%$ de los productores con bajo y medio IDESSP respectivamente, tienen como única fuente de ingreso a la ganadería (Figura 2), lo cual indica uses their ranches for research, while 66.6 and $90 \%$ of farmers with medium and low SPSDI said they have not used their ranches (Table 4). Approximately $75 \%$ of farmers with high SPSDI received instructional advice, however, 55.6 and $50 \%$ of farmers with medium and low SPSDI have only received courses (Figure 1). Similarly, $50 \%$ of producers with high SPSDI noted that the presence of the UNACH on their ranches is high, and as it happened with the previous institution, 55.6 and $70 \%$ of farmers with medium and low SPSDI stated that there was no presence of UNACH in their LUs. According to the above results, it can be noted that producers of high SPSDI have had greater intervention by academic institutions and have received more support in terms of instructional advice, financial aid and presence in their ranches, which justifies having a better developed SPS. This result is consistent with studies in Costa Rica and Colombia where they contended that support that includes technical assistance, plus economic incentives facilitates the adoption of the SPS $(14,15)$ and they also mentioned that the involvement of academic institutions is vital for the adoption of these systems(16).

Figura 2. Productores que tienen ingresos económicos adicionales a la ganadería en Mezcalapa, Chiapas. (SPSDI: alto, medio y bajo)

Figure 2. Producers who have income additional to livestock production in Mezcalapa, Chiapas (SPSDI: High, medium and low)

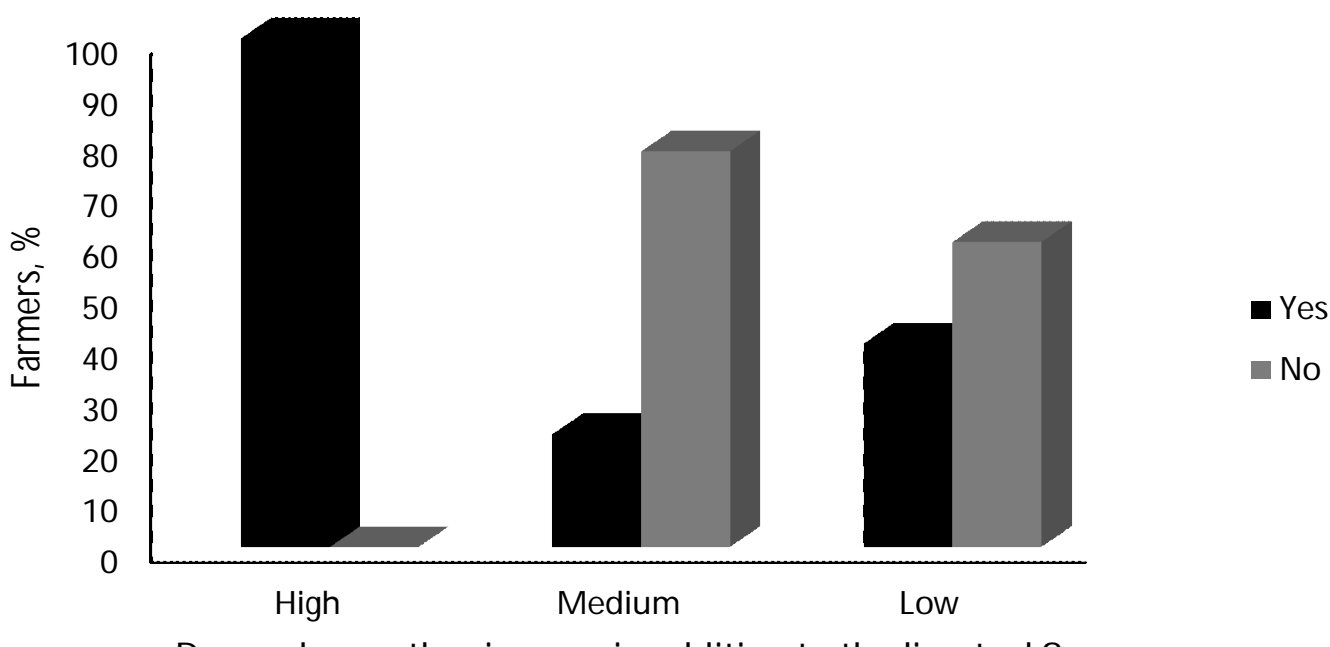

Do you have other income in addition to the livestock? 
que estos últimos tienen menos oportunidad de innovar, debido a limitaciones económicas, como reportaron Aldy et al(17), cuando revelaron que los productores no cambian de un sistema tradicional, más seguro y experimentado, a una nueva tecnología que pudiera estar asociada a riesgos económicos. En promedio, el $93 \%$ de los productores de los tres IDESSP coincidieron en que existe un alto intermediarismo o coyotaje en la venta de los animales, lo que reduce el ingreso por animal y dificulta indirectamente la adopción y desarrollo de alguna modalidad silvopastoril. En un estudio realizado en esta misma región, la ruta de comercialización de los animales vendidos pasan por tres intermediarios, en donde la diferencia entre el precio inicial de venta, por parte del productor, y el precio final de venta por parte de los detallistas, es de $157 \%$, lo que es un margen de comercialización elevado que no beneficia al productor; por tanto, es necesaria una política pública permanente dirigida a resolver los problemas de la cadena productiva, que conduzca a evitar dicho intermediarismo prevaleciente desde la venta del animal en pie, hasta la carne en diferentes cortes, lo que revertiría en una justa y mayor ganancia económica para los productores(18).

Respecto a sus concepciones grupales ante la ganadería, el 50 y $44.4 \%$ de los productores con alto y medio IDESSP, se manifestaron totalmente en desacuerdo con que los nuevos sistemas de producción ganadera son una moda, no así, el $50 \%$ de los productores con bajo IDESSP quienes estuvieron de acuerdo (Cuadro 5). El 50, 77.8 y $60 \%$ de los productores con alto, medio y bajo IDESSP respectivamente, estuvieron totalmente de acuerdo en que la ganadería con base únicamente a pastos afecta la biodiversidad. Así también, la mayoría de los productores en los tres IDESSP estuvieron en desacuerdo y totalmente en desacuerdo con que los árboles afectan el crecimiento de los pastos (Cuadro 5). Al respecto, en Latinoamérica se ha reportado en diferentes estudios la creencia de los productores de que el pasto no crece debajo de los árboles, y es uno de los
Sociocultural factor

All producers (100 \%) with high SPSDI have other income, in addition to livestock, while 77.8 and $60 \%$ of producers with low and medium SPSDI, respectively have as their only source of income livestock production (Figure 2). This suggests that the latter have less opportunity to innovate, due to economic constraints, as reported Aldy et al(17), where they argued that producers do not change from traditional, more secure and experienced system to a new technology that could be associated with economic risks. On average, $93 \%$ of the producers of the three SPSDI agreed that there is a high "coyotaje" or middlemen in the sale of animals, reducing income per animal and indirectly hinders the adoption and progress to some type silvopastoral mode. In a study in this same region, the route of marketing of animals sold go through three intermediaries, where the difference between the initial selling price, by the producer, and the final sale price by retailers, is $157 \%$, which is a high margin for no marketing benefits to the producer; therefore, a permanent public policy aimed at solving the problems of the production chain, leading to circumventing middlemen from the sale of the live animal to the meat in different cuts, which would result in a more just and greater economic gain for the producers(18).

Regarding the perceptions of this group, 50 and $44.4 \%$ of farmers with high and medium SPSDI, expressed total disagreement with that new livestock production systems that are in fashion, while $50 \%$ of producers with low SPSDI favored the new system (Table 5). Farmers with high, medium and low SPSDI, 50, 77.8 and $60 \%$, respectively, fully agreed that raising livestock only with pasture affects biodiversity. Also, most producers in the three SPSDI levels disagreed and some disagreed strongly that trees affect pasture growth (Table 5). In this regard, in Latin America it has been reported in different studies the belief by producers that grass did not growth under the trees, and is one of the factors limiting the adoption of 
Cuadro 5. Factor sociocultural en productores con diferente SPSDI, en Mezcalapa, Chiapas (\%)

Table 5. Sociocultural factor in producers with different Silvopastoral system development index (SPSDI) in Mezcalapa, Chiapas (\%)

\begin{tabular}{|c|c|c|c|}
\hline \multirow[b]{2}{*}{ Indicators } & \multicolumn{3}{|c|}{ SPSDI } \\
\hline & High $(n=4)$ & Medium $(n=9)$ & Low $(n=10)$ \\
\hline \multicolumn{4}{|c|}{ New livestock production systems are a matter of what is in vogue: } \\
\hline Strongly agree & 0 & 22.2 & 10 \\
\hline Agree & 25 & 11.1 & 50 \\
\hline Neither agree nor disagree & 0 & 0 & 0 \\
\hline Disagree & 25 & 22.2 & 20 \\
\hline Strongly disagree & 50 & 44.4 & 20 \\
\hline \multicolumn{4}{|c|}{ Livestock using pastures affects biodiversity: } \\
\hline Strongly agree & 50 & 77.8 & 60 \\
\hline Agree & 25 & 11.1 & 20 \\
\hline Neither agree nor disagree & 0 & 0 & 10 \\
\hline Disagree & 0 & 11.1 & 0 \\
\hline Strongly disagree & 25 & 0 & 10 \\
\hline \multicolumn{4}{|l|}{ Trees affect pasture growth } \\
\hline Strongly agree & 0 & 22.2 & 10 \\
\hline Agree & 0 & 22.2 & 10 \\
\hline Neither agree nor disagree & 0 & 0 & 20 \\
\hline Disagree & 25 & 11.1 & 10 \\
\hline Strongly disagree & 75 & 44.1 & 50 \\
\hline \multicolumn{4}{|c|}{ The younger generations have no interest in farming: } \\
\hline Strongly agree & 50 & 55.6 & 60 \\
\hline Agree & 50 & 22.2 & 20 \\
\hline Neither agree nor disagree & 0 & 11.1 & 20 \\
\hline Disagree & 0 & 11.1 & 0 \\
\hline Strongly disagree & 0 & 0 & 0 \\
\hline \multicolumn{4}{|c|}{ Consideration of annual earnings of LUs: } \\
\hline Very sufficient & 0 & 0 & 0 \\
\hline Sufficient & 25 & 22.2 & 20 \\
\hline Average & 75 & 55.6 & 70 \\
\hline Deficient & 0 & 22.2 & 10 \\
\hline Very insufficient & 0 & 0 & 0 \\
\hline
\end{tabular}

$(P>0.05)$. LUs = Livestock units.

factores que limita la adopción de los SSP(19,20), lo cual, no es un obstáculo para la mayoría de los productores según este estudio.

En los tres niveles del IDESSP, los productores están de acuerdo y totalmente de acuerdo en que las generaciones más jóvenes no tienen interés en el campo; esto puede generar decisiones como la venta del rancho o cambiar
SPS $(19,20)$, which is not an obstacle for most producers according to this study.

At all three levels of SPSDI, producers agree and fully agree that the younger generations are not interested in farming. This can generate decisions such as selling the ranch or switching to other production systems that involve less effort and cost (that surfaced in previous 
a otros sistemas de producción que conlleven menos esfuerzos y costos (esto afloró en los talleres participativos previos a este estudio, próximos a publicarse), continuando así los daños ambientales, como la deforestación, la degradación de pastizales y erosión del suelo entre otros, por lo que, se considera necesaria una política pública para motivar la permanencia o regreso de ellos al campo, una vez concluidos sus estudios.

La mayoría de los productores en los tres niveles del IDESSP, están totalmente de acuerdo con que los productores deben experimentar diferentes alternativas para mejorar la producción del rancho, lo cual se dificulta sin el apoyo de los jóvenes. Por otro lado, el 75, 55.6 y $70 \%$ de los productores con alto, medio y bajo IDESSP consideraron que los ingresos económicos anuales de sus UGs son regulares y están siendo afectados por el alto intermediarismo ya mencionado, el bajo precio que les pagan por litro de leche $(\$ 4.20)$ y la penalización del $50 \%(\$ 2.00)$ de su precio si llegan a detectar algún grado de contaminación.

\section{Factor personal}

En relación a las horas que el productor dedica a las actividades del rancho, el 50, 66.7 y $50 \%$ de los productores con alto, medio y bajo IDESSP respectivamente, señalaron que trabajan entre 5 a $10 \mathrm{~h}$ diarias. El grado de conocimiento sobre los SSP que indicaron tener fue regular, para el $75,77.8$ y $60 \%$ de los productores con alto, medio y bajo IDESSP respectivamente (Cuadro 6), esto indica que en los tres niveles los productores tienen un conocimiento limitado, lo cual frena el proceso de adopción y el desarrollo de estos sistemas, lo cual coincide con Calle et al(5) quienes reportaron que en Latinoamérica la falta de conocimiento, es una de las principales barreras para la adopción de los SSP. Sin embargo, existen diferencias importantes, como puede entreverse por la frecuencia en que los productores introducen árboles forrajeros en las UGs, dado que el $75 \%$ de ellos con alto IDESSP los introducen con participatory workshops of this study, to be published in the near future), continuing environmental damage such as deforestation, grassland degradation and soil erosion among others, so that public policy is considered necessary to motivate their permanence or return to the farm once their studies are concluded.

Most producers at the three levels of SPSDI fully agree that they should consider different alternatives to improve the production of the ranch, which is difficult without the support of young people. On the other hand, 75, 55.6 and $70 \%$ of farmers with high, medium and low SPSDI considered that the annual income of their LUs is average and are being affected by the high intermediarism as mentioned above, the low price they are paid for liter of milk (\$4.20 Mexican pesos) and penalty of $50 \%$ (\$2.00) of the price if they detect some degree of contamination.

\section{Personnel factors}

In relation to the hours that the producer engaged in the activities of the ranch, 50, 66.7 and $50 \%$ of farmers with high, medium and low SPSDI respectively, said they work 5 to $10 \mathrm{~h}$ a day. The degree of knowledge about the SPS indicated an average of 75, 77.8 and $60 \%$ of farmers with high, medium and low SPSDI, respectively (Table 6). This indicates that the three levels of producers have limited knowledge, which slows the process of adoption and development of these systems, which coincides with Calle et al(5), where they reported that in Latin America the lack of knowledge is one of the main barriers to the adoption of the SPS. However, there are important differences, as can be glimpsed by the frequency in which producers introduced fodder trees in LUs, since $75 \%$ of them with high SPSDI introduce them frequently, while 44.4 and $70 \%$ with medium and low SPSDI do it infrequently and regularly. Despite this, producers have become aware of the damage caused to the environment by farming practices previously made as a result 
frecuencia, en tanto que el $44.4 \%$ y $70 \%$ con medio y bajo IDESSP lo hacen de forma poco frecuente y regular. A pesar de lo anterior, los productores han tomado conciencia sobre los daños ocasionados al medio ambiente por la practicas ganaderas que efectuaron of the intervention of ECOSUR and UNACH for $8 \mathrm{yr}$, through a project for certification in production of organic milk, among others, which explains that $100,66.7$ and $70 \%$ of farmers with high, medium and low SPSDI respectively, have such certification.

Cuadro 6. Factor personal en productores con diferente SPSDI, en Mezcalapa, Chiapas (\%)

Table 6. Personnel factor affecting producers with different Silvopastoral system development index (SPSDI) in Mezcalapa, Chiapas (\%)

\begin{tabular}{|c|c|c|c|}
\hline \multirow[b]{2}{*}{ Indicators } & \multirow[b]{2}{*}{ High $(n=4)$} & \multicolumn{2}{|c|}{ SPSDI } \\
\hline & & Medium $(n=9)$ & Low $(n=10)$ \\
\hline \multicolumn{4}{|l|}{ Knowledge of silvopastoral systems: } \\
\hline Good & 0 & 0 & 10 \\
\hline Average & 75 & 77.8 & 60 \\
\hline Poor & 25 & 11.1 & 20 \\
\hline None & 0 & 11.1 & 10 \\
\hline \multicolumn{4}{|l|}{ Use of fodder trees: } \\
\hline Very often & 25 & 0 & 0 \\
\hline Often & 50 & 22.2 & 0 \\
\hline Average & 0 & 22.2 & 70 \\
\hline Uncommon & 25 & 44.4 & 10 \\
\hline Very uncommon & 0 & 11.1 & 20 \\
\hline \multicolumn{4}{|c|}{ Why does producer use his particular production system: } \\
\hline Environmental conservation & 75 & 33.3 & 30 \\
\hline Animal benefit & 25 & 22.2 & 10 \\
\hline Quality products and best price & 0 & 22.2 & 30 \\
\hline Human health benefits & 0 & 0 & 20 \\
\hline Has always worked in this manner & 0 & 22.2 & 10 \\
\hline \multicolumn{4}{|l|}{ Organic certification: } \\
\hline Yes & 100 & 66.7 & 70 \\
\hline No & 0 & 33.3 & 30 \\
\hline \multicolumn{4}{|c|}{ How accessible economically are the products of agricultural enterprises: } \\
\hline Good & 0 & 22.2 & 20 \\
\hline Average & 25 & 22.2 & 50 \\
\hline Poor & 75 & 55.6 & 30 \\
\hline \multicolumn{4}{|c|}{ How suitable are the products of agricultural enterprises: } \\
\hline Good & 50 & 77.8 & 50 \\
\hline Average & 25 & 0 & 40 \\
\hline Poor & 25 & 22.2 & 10 \\
\hline \multicolumn{4}{|c|}{ How effective are the products of agricultural enterprises: } \\
\hline Good & 75 & 66.7 & 70 \\
\hline Average & 0 & 22.2 & 30 \\
\hline Poor & 25 & 11.1 & 0 \\
\hline
\end{tabular}

$(P>0.05)$. 
anteriormente, a consecuencia de la intervención del ECOSUR y la UNACH desde hace ocho años, mediante un proyecto para la certificación en la producción de leche orgánica, entre otros, lo cual explica que el 100, 66.7 y $70 \%$ de los productores con alto, medio y bajo IDESSP respectivamente, resultaran con dicha certificación.

Actualmente, dentro de las razones por las que llevan a cabo su sistema de producción, el 75 , 33.3 y $30 \%$ de los productores con alto, medio y bajo IDESPP respectivamente, señalaron la conservación del medio ambiente, aunque productores de los dos últimos niveles indicaron en un 22.2 y $10 \%$ que su razón es que siempre se ha trabajado así, y destaca que los porcentajes relacionados con el bienestar animal sean descendentes a partir del nivel más alto del IDESSP (Cuadro 6). Los datos muestran que los productores con alto IDESSP son los más concientizados sobre la conservación del medio ambiente, lo que favorece directamente el desarrollo de los SSP en sus UGs. Adicionalmente, el 100, 55.6 y $90 \%$ de los productores con alto, medio y bajo IDESSP respectivamente, señalaron que es necesario realizar acciones para mejorar el medio ambiente.

La percepción que tuvieron los productores sobre los productos de empresas agropecuarias (medicamentos, alimentos comerciales, agroquímicos, etc.) fue que son poco accesibles económicamente para los de nivel alto (75\%) y medio $(55.6 \%)$ y regularmente accesibles (50\%) para los de nivel bajo del IDESSP, en tanto que la mayoría de los tres niveles coincidieron en que son adecuados y efectivos, lo cual indica que los productores, confían en estos productos para resolver los problemas que se presentan en sus UGs a pesar de su costo. En suma, el $50 \%$ de los productores con alto IDESSP mencionaron que el apoyo más importante que necesitan para introducir mejoras en su rancho es el económico, mientras que para los productores con nivel medio (66.7\%) y bajo (40\%) del IDESSP, es en infraestructura.
Currently, it is among the reasons why they carried out their production system, 75, 33.3 and $30 \%$ of farmers with high, medium and low SPSDI respectively, noted the conservation of the environment, but producers of the last two levels indicated at 22.2 and $10 \%$ that their reason is that it has always worked in this manner, and it is notable that the percentages related to animal welfare are down, from the highest level of SPSDI (Table 6). The data show that high SPSDI producers are more sensitized regarding environmental conservation, which directly favors the development of the SPS in their LUs. Additionally, 100, 55.6 and $90 \%$ of farmers with high, medium and low SPSDI respectively, noted that it is necessary to take action to improve the environment.

The perception that producers have regarding products from agricultural enterprises (drugs, commercial foods, chemicals, etc.) was that they are economically inaccessible for high level (75 \%), medium $(55.6 \%)$ and regularly accessible (50\%) for low-level SPSDI. While most at all the three levels agreed that, they are adequate and effective, indicating that producers rely on these products to solve problems that arise in their LUs despite its cost. Summarizing, $50 \%$ of producers with high SPSDI mentioned that the most important type of support that they need to make improvements to their ranch is economic, while for producers with average level $(66.7 \%)$ and low $(40 \%)$ of SPSDI it is in terms of infrastructure.

\section{CONCLUSIONS AND IMPLICATIONS}

Age, schooling and extra income of producers determine the adoption of silvopastoral systems. The lack of additional revenue, marketing problems such as the low price of milk and the sale of animals through intermediaries (coyotaje) have unmotivated and affects $68.9 \%$ of producers. Many just meet their basic needs, especially those who have no additional source of income and it is clear that this situation causes the younger generations to not be interested or have an affiliation for the farm. At 


\section{CONCLUSIONES E IMPLICACIONES}

La edad, escolaridad e ingreso extra de los productores determinan la adopción de los sistemas silvopastoriles. La falta de ingresos adicionales, los problemas de comercialización como el bajo precio de la leche y la venta de los animales a través de intermediarios (coyotaje), los desmotiva y afecta al $68.9 \%$ de ellos, puesto que apenas satisfacen sus necesidades básicas, a excepción de los que tienen otra fuente de ingresos y tienen claro que esta situación origina que las generaciones jóvenes no tengan interés ni apego al campo. En los tres niveles del IDESSP los productores tuvieron un conocimiento regular sobre los SSP, y señalaron necesitar mayor asesoría técnica de instituciones gubernamentales, académicas y de investigación, así como otras estrategias de intervención para conocer y adoptar la tecnología de esta modalidad agroforestal y sus beneficios; así como, mejores políticas públicas, que contemplen el pago de servicios ambientales, procedimientos más accesibles para lograr apoyos económicos y no sólo como grupo, sino también de manera individual, servicios médicos, becas para el estudio de sus hijos, entre otros, que incentiven a esta población primaria. El índice de desarrollo de SSP generado es una herramienta que permitirá dar seguimiento a las unidades ganaderas en esta zona.

\section{AGRADECIMIENTOS}

Al Sistema Institucional de Investigación de la Universidad Autónoma de Chiapas (SIINVUNACH), por el financiamiento otorgado para la realización del proyecto en el que obtuvo la maestría el primer autor. Se expresa un reconocimiento a los productores participantes por su colaboración en el presente estudio.

\section{LITERATURA CITADA}

1. Ibrahim M, Rojas J, Sinclair F, Villanueva C. Tecnologías forrajeras para la intensificación de la ganadería y la all three levels of SPSDI producers said they had average knowledge of SPS, noting that they need further technical assistance from the government, academic and research institutions and other intervention strategies to learn and adopt the technology of agroforestry methods and its benefits. Needed as well are better public policies, providing for the payment of environmental services with more accessible procedures to achieve economic support, not only as a group but individually, as well as medical services, scholarships for the study of their children, among others, to encourage this primary population. The SPS development index generated is a tool that allows for tracking of livestock units in this area.

\section{ACKNOWLEGMENTS}

Institutional Research System of the Universidad Autonoma de Chiapas (SIINV-UNACH), for the funding provided for the project in which first author obtained his MS degree. We expressly thank the participating producers for their assistance in this study.

End of english version conservación de los recursos naturales en el trópico. En: Velasco ZME, Pinto RR, Martínez CB. Simp Int Forrajes Trop Prod Anim. México: UNACH; 2005:77-94.

2. Montagnini F, Finney C. Payments for environmental services in Latin America as a tool for restoration and rural development. Ambio 2011;(40):285-297.

3. González J. Costos y beneficios de un sistema silvopastoril intensivo (SSPi), con base en Leucaena leucocephala (Estudio de caso en el municipio de Tepalcatepec, Michoacán, México). Avanc Invest Agropecu 2013;17(3):35-50.

4. Calle Z, Murgueitio E, Chará J. Integración de las actividades forestales con la ganadería extensiva sostenible y la restauración del paisaje. Unasylva 2012;63(1):31-38.

5. Murgueitio E, Chará J, Solarte A, Uribe F, Zapata C, Rivera J. Agroforestería pecuaria y sistemas silvopastoriles intensivos (SSPi) para la adaptación ganadera al cambio climático con sostenibilidad. Rev Col Cienc Pecu 2013;(26):313-316.

6. Xóchitl M, Solorio B. Ganadería sustentable, 2a Etapa del proyecto estratégico de prioridad nacional "Desarrollo y fomento de los sistemas silvopastoriles intensivos como 
Rubén Manuel Zepeda Cancino, et al. / Rev Mex Cienc Pecu 2016; 7(4):471-488

alternativa alimenticia para la producción de carne y leche en regiones tropicales de México". 1a ed, México: Fundación Produce A.C. Michoacán. 2013.

7. Nahed TJ, Calderón PJ, Aguilar JR, Sánchez MB, Ruiz RJ, Mena $Y$, et al. Aproximación de los sistemas agrosilvopastoriles de tres microrregiones de Chiapas, México, al modelo de producción orgánica. Avanc Invest Agropecu 2009; 13(1): 45-58.

8. Nahed TJ, Sánchez MB, Ruiz RJ, Delgadillo PC, Guevara HF. Innovación socio ambiental desde la perspectiva pecuaria: El caso de la transición orgánica en Tecpatán, Chiapas. En: Bello BE, Naranjo PE, Vandame R editores. La otra innovación para el ambiente y la sociedad en la frontera sur de México, México: ECOSUR; 2012:134-144.

9. Morgan L. Practical strategies for combining qualitative and quantitative methods: applications to health research. Sage Publications 1998; (3):362-376.

10. Salas JM, Leos JA, Sagarnaga M, Zavala MY. Adopción de tecnologías por productores beneficiarios del programa de estímulos a la productividad ganadera (PROGAN) en México. Rev Mex Cienc Pecu 2013;4(2):243-254.

11. Marín Y, Ibrahim M, Villanueva C, Ramírez E, Sepúlveda C. Los impactos de un proyecto silvopastoril en el cambio de uso de la tierra y alivio de la pobreza en el paisaje ganadero de Matiguas, Nicaragua. Agroforestería de las Américas 2006; (45): 109-116.

12. Forero C, Rojas G, Arguelles J. Capital social y capital financiero en la adopción de tecnologías ganaderas en zonas rurales altoandinas de Colombia. Corpoica Cienc Tecnol Agropecu 2013; 14(2): 149-163.

13. Casasola F, Ibrahim M, Sepúlveda C, Ríos N, Tobar D. Implementación de sistemas silvopastoriles y el pago de servicios ambientales en Esparza, Costa Rica: una herramienta para la adaptación al cambio climático en fincas ganaderas. En: Sepúlveda C, Ibrahim M. Políticas y sistemas de incentivos para el fomento y adopción de buenas prácticas agrícolas como una medida de adaptación al cambio climático en América Central, Costa Rica. CATIE 2009:169-188.

14. Pagiola S, Arcenas A, Platais G. Can payments for environmental services help reduce poverty? An exploration of the issues and the evidence to date from Latin America. World Develop 2005; 33(2):237-253.

15. Zapata A, Murgueitio E, Mejía C, Zuluaga A, Ibrahim M. Efecto del pago por servicios ambientales en la adopción de sistemas silvopastoriles en paisajes ganaderos de la cuenca media del río La Vieja, Colombia. Agroforestería de las Américas 2007; (45):86-92.

16. Plazas B, Lascano C. Utilidad de Cratylia argentea CV. Veranera en sistemas de producción de leche: lecciones aprendidas con productores en el piedemonte de los llanos orientales de Colombia. Velasco ZME, Pinto RR, Martínez CB. editores. Simp Int Forrajes Trop Prod Anim. México: UNACH; 2005:67-76.

17. Aldy J, Hrubovcak J, Vasavada J. The role of technology in sustaining agriculture and the environment. Ecological Econom 1998; (26):81-96.

18. Calderón J, Nahed J, Sánchez B, Herrera O, Aguilar R, Parra M. Estructura y función de la cadena productiva de carne de bovino en la ganadería ejidal de Tecpatán, Chiapas, México. Avanc Invest Agropecu 2012;16(2):45-61.

19. Clavero T, Suarez J. Limitaciones en la adopción de los sistemas silvopastoriles en México. Pastos y Forrajes 2006;29 (3): $1-6$.

20. Mahecha L. Importancia de los sistemas silvopastoriles y principales limitantes para su implementación en la ganadería colombiana. Rev Col Cienc Pecu 2003;16(1):11-18. 